ORGGINAL PAPERS

(7)
二重温度交換反応法による重水濃縮

カスケードの設計

\section{1. 粕 霉}

安定同位元素の工業的分離法としては，a）電解法，

b）蒸溜法，c）交換反応法，d）二重温度交換反応法广 どがあるが，最近重水，明素の分離などで二重温度交換 反応法が問題になってきた。この方法は低温，高温の二 つの塔をすっていて，最適分離カスケードの設計は複雑 であるが，重水の低濃度濃縮にはきわめて有利な方法と 考えられる。

E. W. Becker 1) は適当な液相触媒を用いる水一水素系 の重水菜交換反応法により，固体鰠媒層が不要となり， 通常の気液接触装置の使用が可能となるので、エネルギ 一消費扣上び建滾費の見地から，鳋媒を用いる水蒸気一 水素系の二重温度交換法に比して著しく経瀜的となるこ とを指摘した。一般に同位元素を分離するとき，目的と する同位元素の天然存在比が低いことが多く，またその 分離保数す小さいので多数の分離要素を結合したカスケ ード方式をとることが普通である。二重温度交換反応塔 のカスクードとして Fig. 3 に示すことく，第（i+1） ステージの廃戈流を，第 $\mathrm{i}$ ステージの原料流炕返却する “上部返却カスケード”と，Fig. 4 沉示すことく，第 (i +1）ステージの廃菓流を第 $\mathrm{i}$ ステージの高温塔の上部 に返却する“中央部返却カスケード”とがあり，それぞ れ飞液側循䢬ガス取出し，およびガス側循還液取出しの 㘯合がある。

二重温度交換反応塔の設計法に関しては従来 2，3の 提案がなされている。Cerrai”らは水蒸気水素系単一交 換反応塔の分離保数を導き，総流量および所要エネルギ 一を推算した。また K. Bier ${ }^{5}$ は水一水素系交換反応塔

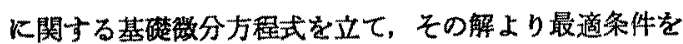
求めた。その他 McCabe-Thiele 線図を適用する方法る 提案されている。しかしこれらはいずれる単一交換反応 塔の最適条件を求めているに過きない。著者らはかかる 気液接触型の二重温度交換反応塔の理論的解析を行い, 同時に低濃度签縮を目的とする最適カスケードの設計法 とつき考察した。重水素の洤縮を目的とする気液接触型

* 昭和 33 年 9 月 5 日受理

1,2 京都大学工学研究所

4,6 京都大学工学部化学機械学数室

3 担化成株式会社

5 的西雷力株式会社
水科 篤郎 ${ }^{1} \cdot$ 高松武一郎 ${ }^{2} \cdot$ 河野 正志 $^{3}$

吉田 昭夫 ${ }^{4}$ - 佐山 隼敏 ${ }^{5}$-中西 英二6

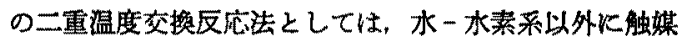
を必要としない酼化水素一水系などがあり，また硼素の 同位元素の分離などる問題になるが著者らの行なった理 論的解析の結果恃，一般の二重温度交换法による同位元 素分離カスケードに適用可能なるのである。数值計算に 上る比較検討は水一水素系の二重温度交换反応について 行なった。

\section{2. 単一二重温度交換反応塔の分䧿係数}

\section{$2 \cdot 1$ 単一交換反応塔} の基硉式

Fig. 1 と示すことを 向流の水 - 水素系箪一交 換塔を考える。ここで各 段は交換平衡が達成され ている理想段とする。低 濃度領域では，重水素は HD, HDO の形で存在す ると考えてよいので，交 換反応としては次式のみ

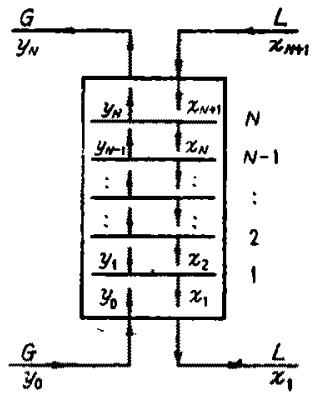

Fig: 1

Single exchange column を考えればよい。

$$
\mathrm{H}_{2} \mathrm{O}(l)+\mathrm{HD}(\mathrm{g}) \rightleftarrows \mathrm{HDO}(l)+\mathrm{H}_{2}(\mathrm{~g})
$$

したがって平衡佰数 $K$ は

$$
K=[\mathrm{HDO}]\left[\mathrm{H}_{2}\right] /\left[\mathrm{H}_{2} \mathrm{O}\right][\mathrm{HD}]
$$

であるが低濃度領域では

$$
K \cong[\mathrm{HDO}] /[\mathrm{HD}]=x / y
$$

そなる。それゆ交換反応塔の各段では，(3）式より

$$
K=x_{1} / y_{1}=x_{2} / y_{2}=\cdots \cdots=x_{N} / y_{N}
$$

第 1 段の物翼収支より

$$
G\left(y_{0}-y_{1}\right)=L\left(x_{1}-x_{2}\right)
$$

ここで $G / L=r, G / L K=r / K=A$ とおくと

$$
x_{2}=A \gamma y_{0}-(1+A)\left(r y_{0}-x_{1}\right)
$$

第 2 段についてる同様な物䫓収支式に（6）の関係を入れ ると

$$
x_{3}=A^{2} \gamma y_{0}-\left(1+A+A^{2}\right)\left(\gamma y_{0}-x_{1}\right)
$$

一般に $N$ 段注いては

$$
\begin{aligned}
x_{N+1}= & A^{N} \cdot r \cdot y_{0}-\left(1+A+A^{2}\right. \\
& \left.+\cdots \cdots \cdots+A^{N}\right)\left(r \cdot y_{0}-x_{1}\right)
\end{aligned}
$$


（8）式の両辺より $x_{1}$ を差引けば

$$
\begin{aligned}
x_{N+1}-x_{1} & =\left(A \cdot x_{1}-\gamma \cdot y_{0}\right) \\
& \left(1+A+A^{2}+\cdots \cdots+A^{N-1}\right)
\end{aligned}
$$

また（8）式の両边上り $K \cdot y_{0}$ を差引洔

$$
\begin{gathered}
x_{N+1}-K \cdot y_{0}=\left(A \cdot x_{1}-r \cdot y_{0}\right)\left(1+A+A^{2}\right. \\
\left.+\cdots \cdots+A^{N}\right) / A
\end{gathered}
$$

(9) 式, (10) 式より

$$
\begin{aligned}
\left(x_{N+1}-x_{1}\right) /\left(x_{N+1}-K \cdot y_{0}\right)=A\left(1+A+A^{2}+\right. & \\
& \left.\cdots \cdot+A^{N-1}\right) /\left(1+A+A^{2}+\cdots \cdots+A^{N}\right) \\
= & \left(A^{N+1}-A\right) /\left(A^{N+1}-1\right)
\end{aligned}
$$

(11) 式で, $\left(A^{N+1}-A\right) /\left(A^{N+1}-1\right)=\varphi(A)$ と拈き，r $y_{0}$ について解けば,

$$
r \cdot y_{0}=\frac{\varphi(A)-1}{\varphi(A)} \cdot A \cdot x_{N+1}+\frac{A}{\varphi(A)} \cdot x_{1}
$$

\section{$2 \cdot 2$ 単一二重温度交換反} 応塔の分踓保数

Fig. 2 のことき低温塔 $N$ 段，高温塔 $M$ 段の二重温度 交換反応塔で

$$
\begin{aligned}
& A_{l}=r_{l} / K_{l}, A_{h}=\gamma_{h} / K_{h} \\
& \varphi\left(A_{l}\right)=\left(A_{l}{ }^{N+1}-A_{l}\right) / \\
&\left(A_{l}{ }^{N+1}-1\right) \\
&\left(A_{l} \neq 1\right) \\
& \psi\left(A_{h}\right)=\left(A_{k}{ }^{H+1}-A_{h}\right) / \\
&\left(A_{k}{ }^{M+1}-1\right) \\
&\left(A_{h} \neq 1\right)
\end{aligned}
$$

そおくと，(12）式は

低温落：

$$
\begin{array}{r}
y_{0}=\frac{\varphi\left(A_{l}\right)-1}{\varphi\left(A_{l}\right)} \cdot \frac{A_{l}}{r_{l}} \quad \text { A dual exchang } \\
\cdot x_{N+1}+\frac{1}{\varphi\left(A_{l}\right)} \cdot \frac{A_{l}}{r_{l}} \cdot x_{1}
\end{array}
$$

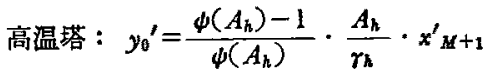

$$
+\frac{1}{\psi\left(A_{h}\right)} \cdot \frac{A_{h}}{r_{h}} \cdot x_{1}^{\prime}
$$

となる。

液取り出しの場合の頭部分離係数 $B_{2}$ ，尾部分離係数 的は，それぞれの存在比の比で定義されるが，低濃度領 域では近似的に組成の比であらわされ

$$
\begin{aligned}
& \beta_{L}=\frac{x_{1}\left(1-x_{N+1}\right)}{x_{N+1}\left(1-x_{1}\right)} \cong x_{1} / x_{N+1} \\
& \alpha_{L}=\frac{x_{1}\left(1-x_{1}^{\prime}\right)}{\left(1-x_{1}\right) x_{1}^{\prime}} \cong x_{1} / x_{1}^{\prime}
\end{aligned}
$$

ガス取出しの場合の分離係数も同様似

$$
\begin{aligned}
& \beta_{G} \cong y_{M}{ }^{\prime} / y_{0}{ }^{\prime} \\
& \alpha_{G} \cong y_{M^{\prime}} / y_{N}
\end{aligned}
$$

塔を設計し解析する場合, 頭部分離係数 $\boldsymbol{\beta}$ が液ガス比 $r$ ，塔段数 $N ， M$ また操作条件なとにより，いかに变化 するかを知らね快ならない。つき境界条件を代入して (13)，(14）式上りそれらの関係式を誘導しよ5。

i）上部返却，カス循遗，液取出しの場合これは Fig. 3 に示すことく，ガスを循還し，液を取り出す上部 返却カスィードで，低温塔を出る濃縮液流の一部(カッ ト，日）はつぎのステージに行き他の一部 $(1-\theta)$ は高温 塔の塔頂に入る。この場合, 低温塔頂部出口と高温落底 部入口のガス灌度，低温塔底部入口と高温塔頂部出口の ガス濃度，および低温塔底部出口と高温塔頂部入口の液 漕度はそれぞれ等しい。すなわち

$$
\begin{aligned}
& y_{N}=y_{0}{ }^{\prime} \\
& y_{0}=y_{M}{ }^{\prime} \\
& x_{1}=x^{\prime}{ }_{M+1}
\end{aligned}
$$

したがって定常状態を考えれば，全体の物質収支より

$$
x_{N+1}=\theta \cdot x_{1}+(1-\theta) x_{1}^{\prime}
$$

さらに低温塔の物質収支より

$$
r\left(y_{0}-y_{0}^{\prime}\right)=\left(x_{1}-x_{N+1}\right)
$$

(21)，(22）式を（13）（14）式に代入して $x_{1}{ }^{\prime} ， x^{\prime}{ }_{M+1}$ を消去し（23）式と結びつけ， $x_{1}, x_{N+1}$ のみの函数とし $\tau \beta \cong x_{1} / x_{N+1}$ を求め机ば，液側頭部分離係数 $\beta_{U L}$ は

$$
\beta_{U L}=\frac{A_{l} / \varphi\left(A_{l}\right)+A_{h} / \psi\left(A_{h}\right)-\left(1+A_{l}\right)}{A_{l} / \varphi\left(A_{l}\right)+A_{h} / \psi\left(A_{h}\right)-\left(1+A_{h}{ }^{0}\right)}
$$

ここで

$$
\begin{aligned}
& A_{h}=\gamma_{l} /(1-\theta) K_{h} \\
& A_{h}{ }^{0}=(1-\theta) A_{h}=\gamma_{l} / K_{h}
\end{aligned}
$$

ii）上部返却, 液循缱, カス取出しの場合 前と同 様な上部返却カスケードで，液を循還し，ガスを高温荅 底部より入れ，高温塔で浱縮させ，その一部はつきのス テージに行き，他の一部は低温荅底部に入る。この埸合 境界条件として。

$$
x_{N+1}=x_{1}^{\prime}
$$

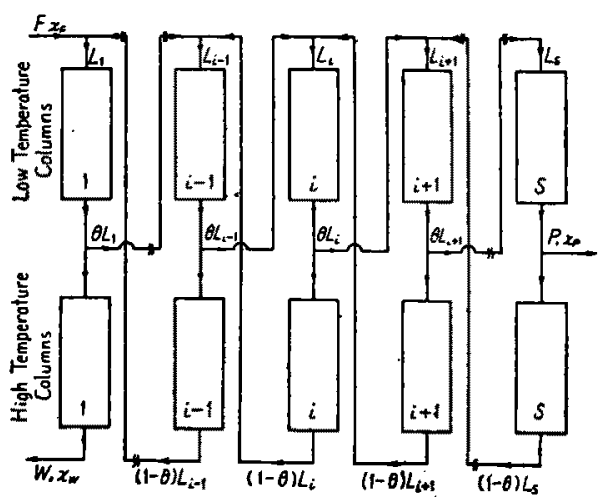

Fig. 3 Non-Mixing cascade 


$$
\begin{aligned}
& x_{1}=x_{M+1}^{\prime} \\
& y_{0}=y_{M}^{\prime}
\end{aligned}
$$

したがって高温荅の物賀收支より

$$
x_{1}-x_{1}^{\prime}=r\left(y_{0}-y_{0}^{\prime}\right)
$$

(25)，（26)，(13)，(14)，（28）式などを用い， $\cong \cong y_{0} /$ $y_{0}^{\prime}$ を求めれば，ガス側頭部分就保数 $\beta_{U G}$ は

$$
\beta_{U . G}=\frac{1 / \varphi\left(A_{l}\right)+1 / \psi\left(A_{h}\right)-\left(1+1 / A_{k}\right)}{1 / \varphi\left(A_{l}\right)+1 / \psi\left(A_{k}\right)-\left(1+1 / A_{l}{ }^{0}\right)}
$$

ただし $A_{l}{ }^{\mathrm{B}}=A_{l} /(1-\theta)=\gamma_{h} / K_{h}$

iii）中央部返却、ガス循远，淁取出しの場合これ は Fig. 4 に示すことく，ガス側を循還し，液は低温荅 頂部より入り洅樎され，その一部はつきのステージ行 き，他の一部とつきのステーシよりの廃棄流とが高温荅 に入る。この塨合上部返却の場合と異なり，低温落と高 温荅の間で低濃度の廃裹流が入るため，低温塔底部と高 温荅項部の液側濃度は等しくならない。したがって境界 条件は

$$
\begin{aligned}
& y_{N}=y_{0}^{\prime} \\
& y_{0}=y_{M} \\
& x_{M+1}^{\prime}=(1-\delta) x_{1}
\end{aligned}
$$

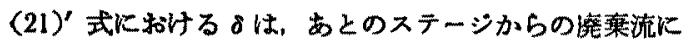

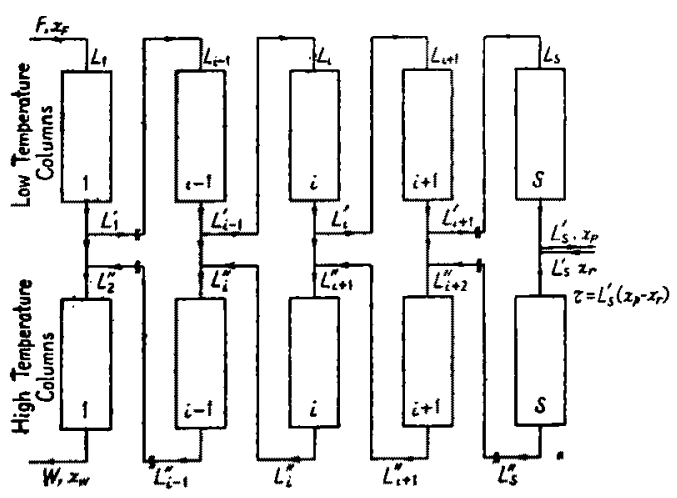

Fig. 4 Mixing cascade

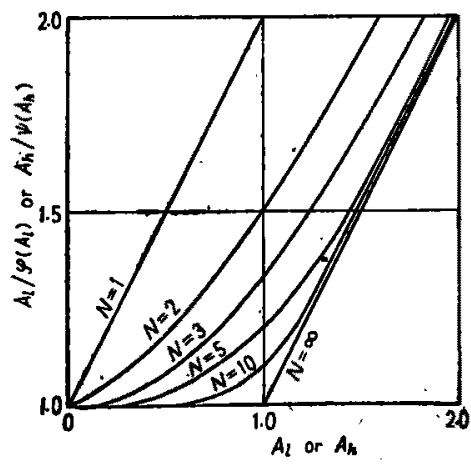

Fig. $5^{\circ} A$ vs $A / \varphi(A)$

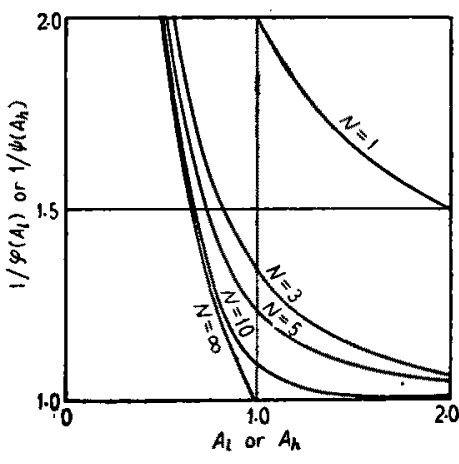

Fig. $6 A$ vs $1 / \varphi(A)$

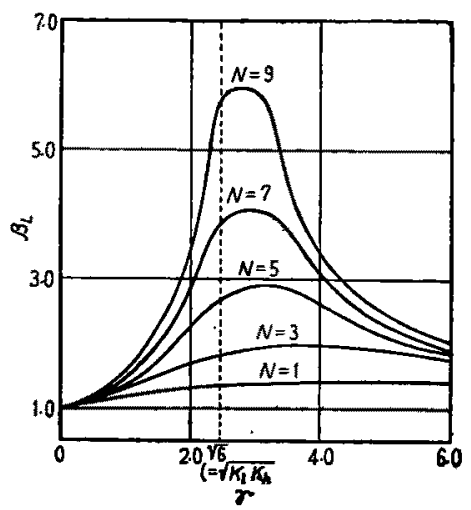

Fig. $7 \quad r$ vs $\theta_{L}$ in total reflux

これら (24)，(29)，(30)，(31）式の頭部分離係数 $\boldsymbol{\beta}$ の值を求めるには, Fig. 5, 6 のことく $A$ 対 $A / \varphi(A)$, $A$ 对 $1 / \varphi(A)$ を線図にして拈くと便利である。Fig. 5, 6 の線图を用いて全僄流の場合の単一二重温度交換反応塔 の $\boldsymbol{\gamma} \boldsymbol{B}$ 関係を $N=M$ の場合について $N$ をバラメーター として Fig. 7，8 K示した。Fig. 7 は液側分離係数 $\boldsymbol{\beta}_{\boldsymbol{L}}$ を，Fig. 8 はガス揑分離係数 $\boldsymbol{B}_{G}$ を示している。なお， $N$ が等しい昜合承者は $\gamma=\sqrt{K_{l} \cdot K_{h}}$ の点で交わり，その 分離係数の最大値は同じ段数の場合ほぼ同じ値を示す。 


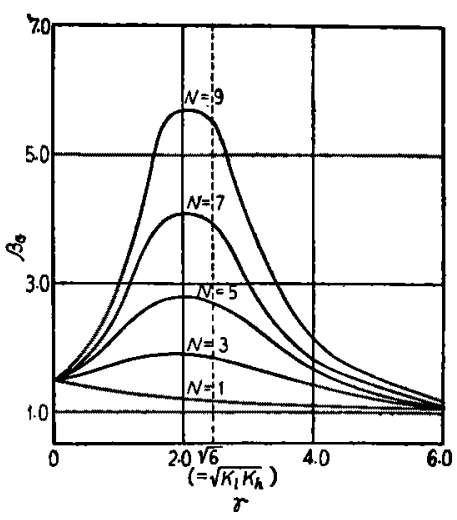

Fig. $8 \quad r$ vs $\beta_{G}$ in total reflux

また分蜼保数の最大值を与学る $\gamma$ の値は Fig. 7 では $\gamma=$ $\sqrt{K_{l} \cdot K_{\mathrm{h}}}$ より大きく, Fig. 8 では $r=\sqrt{K_{l} \cdot K_{\mathrm{h}}}$ より小さ

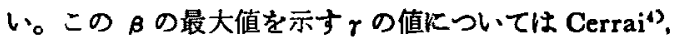
Bier ${ }^{5)}$ のえた結果と一致している。

\section{$2 \cdot 3$ 頭部分離係数と尾部分政保数との関係}

前節i) iv) 飞沶いてては頭部分離保数 $\beta$ を段数，拉上 び操作条件の函数としてあらわしたっっきに尾部分離俰 数 $a$ 頭部分離係数 $\mathrm{A}$ の関保を求めてみる。Fig. 3 の ことき上部返却の場合，定常状態ては

$$
L\left(x_{1}-x_{N+1}\right)=(1-\theta) L\left(x^{\prime}{ }_{M+1}-x_{1}^{\prime}\right)
$$

境界条件，拈よび(15)，(16) 式よりつぎの関俰式がえ られる。

$$
1 /(1-\theta)=(\alpha-1) / \alpha \cdot \beta /(\beta-1)
$$

また Fig. 4 のことき中央部返却の場合，定常状熊で は

$$
L_{l}\left(x_{1}-x_{N+1}\right)=L_{k}\left(x^{\prime}{ }_{M+1}-x_{1}^{\prime}\right)
$$

境界条件，(15)，（16）式上り $\alpha ， \beta$ の関係は

$$
\alpha=1 /[(1-\delta)-1 / m \cdot(1-1 / \beta)]
$$

\section{3. 二重温度交換反応カスケードの基喽式}

カスケードの最適条件とは，ある濃度の製品を一定量 生産するのにコストが最小となる条件をいら。したがっ て二重温度交換法では建設費が近似的に総落容積に比例 するすのとすれば，建設費が最小になるカスケードの最 適条件を求めることは，一定暧度一定量の製品を作るの に必要なカスケードの総塔容皘を最小とする操作条件な らびにカスケード方式を決定することに州結される。

第 $\mathrm{i}$ ステージの荅容積を表わす式恰塔断面皘Qと塔高 さ $Z$ の積で表わされる。

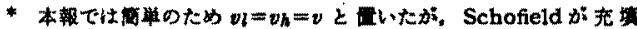

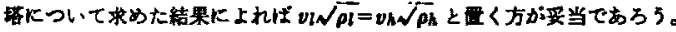

** $\alpha=\beta^{2}$ なるカスタードでは. $\beta>1$ でければならないのて, $\theta<$

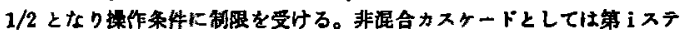

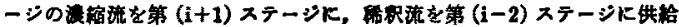

$$
V_{i}=\left(Q_{1}\right)_{i}\left(Z_{l}\right)_{i}+\left(Q_{n}\right)_{i}\left(Z_{k}\right)_{i}
$$

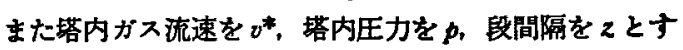
ると

$$
\begin{gathered}
Z_{l}=N z, \quad Z_{k}=M z \\
Q_{l}=G_{l} \cdot R \cdot T_{l} / p \cdot v, \quad Q_{k}=G_{k} R T_{k} / p v
\end{gathered}
$$

(37)（38）式を（36）式に代入し，さらに $M / N=\kappa$ と おけば

$$
V_{i}=(R z / p v) N_{i}\left[G_{l} T_{l}+G_{h} T_{h}\right]_{i}
$$

\section{$3 \cdot 1$ 上部返却カスケート}

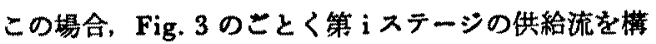

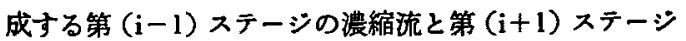
の稀釈流の濃度が等しいカスケード，すなわち非混合カ スケードに組むのが普通である。この非混合カスケード の場合は

$$
\begin{aligned}
& \left(x_{1}\right)_{i}=\beta\left(x_{N+1}\right)_{i}=\beta^{2}\left(x_{N+1}\right)_{i-1}=\alpha\left(x_{1}^{\prime}\right)_{i} \\
& \left(x_{N+1}\right)_{i-1}=\left(x_{1}^{\prime}\right)_{i}
\end{aligned}
$$

したがって, $\alpha=\beta^{2 * *}$

が成立するから，この条件と $\boldsymbol{\alpha}^{-\boldsymbol{\beta}}$ 関係（33）式とより， 非混合条件を满足する

$$
\boldsymbol{\beta}=(1-\theta) / \theta
$$

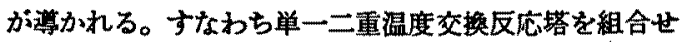
て上部返却非混合カスケードにする場合，各塔の分離係 数は常に (40) 式の関保を満していなければならない。 したがって上部返却カスケードを解析する場合，非混合 条件を满足する月対

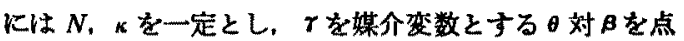

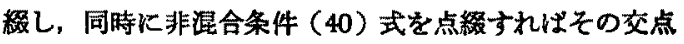
より非混合条件を满足する $\beta$ 対 $\gamma$ が求められる。

i） カス循逼液取出しの場合（39）式に $\left(G_{l}\right)_{i}=$ $\left(G_{h}\right)_{i}=r_{i}\left(L_{l}\right)_{i}$ を代入すれば，第 $\mathrm{i}$ ステージの

$$
V_{i}=N_{i}(R z / p v)_{i}\left(T_{l}+{ }_{k} T_{h}\right)\left(L_{l}\right)_{i}
$$

したがってカスケードの全ステージを $S$ ，カスケードを 通して $N, \kappa, r ， p ， v ， z, T_{l}, T_{h}, \beta, \theta$ などを一定に とると, カスケードの総荅容積 $V$ は

$$
V=\sum_{i=1}^{S} V_{i}=N z \gamma(R / p v)\left(T_{l}+\kappa T_{\mathrm{n}}\right) \sum_{i=1}^{S}\left(L_{l}\right)_{i}
$$

非混合カスケードの循還量は Cohen ${ }^{22}$, Benedict ${ }^{32}$ らK

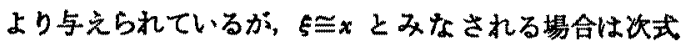
で与えられる。

$$
\sum_{i=1}^{S}\left(L_{l}\right)_{i}=\frac{(\beta+1)}{(\beta-1) \ln \beta}\left[F \ln x_{F}-P \ln x_{P}-W \ln x_{W}\right]
$$

総塔容積 $V$ を示す式を，濃度を表わす項 $D^{* * *}$ と，塔型

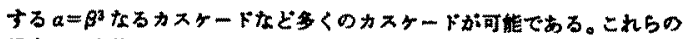

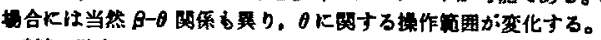

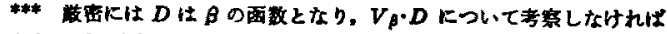
ならないが、本報では $D$ のによる影が少ないたか t。 
式を表わす項 $V_{w}{ }^{\beta}$ の函数となっている項 $V_{\beta}$ に分滩す れば

$$
\begin{aligned}
& V=V_{Q} V_{\beta} D \\
& V_{\nu}=R z / p v \\
& V_{\beta}=N \gamma\left(T_{l}+{ }_{k} T_{h}\right)(\beta+1) /(\beta-1) \ln \beta \\
& D=F \ln x_{F}-P \ln x_{P}-W \ln x_{W}
\end{aligned}
$$

したがって総塔容皘 $V$ を最小にするためには $V_{v}, V_{\beta} を$ それぞれ最小炕しなけれ怆ならない。しかしながら使用 する気液接触装圈侻関する塔内流速，段間隔なとは通常 の化学工学の問題であるので, ここではカスケードの特 性を示す $V_{\beta}$ を最小にする $r, \kappa ， N$ などを考察するにと どめる。

ii）液循逼ガス取出しの場合 上部返却非混合カス ケードでガスを取出す場合， $\left(G_{l}\right)_{i}=(1-\theta)\left(G_{h}\right)_{i}$ を(39) 式比代入すれば，総塔容䖽は

$$
V=N z(R / p v)\left\{(1-\theta) T_{l}+\kappa T_{h}\right\} \sum_{i=1}^{S}(G h)_{i}
$$

$\sum_{i=1}^{S}\left(G_{h}\right)_{i}$ はガス濃度を用いれば (43) 式と同様になるた め, この場合の $V_{\beta}$ は

$$
V_{\beta}=N\left[(1-\theta) T_{1}+{ }_{k} T_{h}\right](\beta+1) /(\beta-1) \ln \beta
$$
となる。

\section{$3 \cdot 2$ 中央部返却カスケート}

Fig. 4 のことき中央部返却カスケートにおいて， $m=$ $r_{l} / r_{h}$ が各ステーシことに変化するため, 解析が非常汇困 難となる。しかしながら Bier す指摘していることく， 低濃度濃縮カスタードに括いて取出し量の影遙が非常に 少ないため，最終ステージの濃樎流より一定の割合で制 品を取り出し，それより低濃度の液またはガスを取出し 量と同しだけ加えるようなカスケード近似でき，この 場合 $m=\gamma_{i} / \gamma_{k}=1$ となり解析は容易となる。したがって 本報では $m=1$ の場合について考察することにする。上 部返却の場合と同様にカスケードを通して $N, \kappa, r, p$, $v, z, T_{h}, T_{h}, \beta, \delta$ を一定とし, 第 $\mathrm{i}$ ステージ以下の物質 収支を考学れば Fig. 4 から明らかなようにステージ間 の流量は等しく，

$$
L_{i} \cdot\left(x_{1}\right)_{i}-L_{i}\left(x^{\prime}{ }_{M+1}\right)_{i}=\tau=F\left(x_{F}-x_{W}\right)
$$

ここでては所要同位元素移動量である。境界条件 (21) 式を代入すれば

$$
L_{i}=F\left(x_{F}-x_{W}\right) / \beta \delta\left(x_{N+1}\right)_{i}
$$

(51) 式より第1ステーシに和ける関係は

$$
F=\tau / \beta \delta x_{F}
$$

ゆえに

$$
\beta \delta=-\not / F x_{F}
$$

また総流量泆

$$
\sum_{i=1}^{S} L_{i}=\tau / \beta \delta \cdot\left(1 / x_{F}+1 / \beta \cdot x_{F}+\cdots \cdots+1 / \beta^{S-1} x_{F}\right)
$$

（52）式を代入して

$$
\sum_{i=1}^{S} L_{i}=\beta /(\beta-1) \cdot F\left(1-x_{F} / x_{P}\right)
$$

i）ガス循遗液取出しの場合 上部返却カスケード の場合々同样にして

$$
V=N z r(R / p v)\left(T_{l}+{ }_{k} T_{h}\right) \sum_{i=1}^{S} L_{i}
$$

(53) 式の $\sum_{i=1}^{S} L_{i}$ を(54) 式に用いると

$$
\begin{aligned}
& V_{\beta}=\gamma N\left(T_{1}+{ }_{\kappa} T_{h}\right)_{\beta} /(\beta-1) \\
& D=F\left(1-x_{F} / x_{P}\right)
\end{aligned}
$$

ii）液循僄ガス取出しの場合上暗返却の場合と同 㥞にすれば，総塔容積は

$$
V=N z(R / p v)\left(T_{l}+{ }_{k} T_{h}\right) \sum_{i=1}^{S} G_{i}
$$

ここで $\sum_{i=1}^{S} G_{i}$ はガス濃度を用いれば（53）式と同じ になり

$$
\begin{aligned}
& V_{\beta}=N\left(T_{1}+{ }_{k} T_{h}\right) \beta /(\beta-1) \\
& D=F\left(1-x_{F} / x_{P}\right)
\end{aligned}
$$

\section{4. カスケードの最適条件}

前述のことく建設費は塔容鈢に比例するとし，塔容皘 を最小にする最適条件， $N_{\text {opt }}$, $\kappa_{\text {opt }}$, ropt, $\beta_{\text {opt }}, \delta_{\text {opt }}$. 弚 などを考察してみよう。数值解析は，水一水素系交 換反応塔について行い，低温塔温度 $70^{\circ} \mathrm{C}\left(K_{l}=3.00\right)$, 高温塔温度 $200^{\circ} \mathrm{C}\left(K_{k}=2.00\right)$ の場合について行った。

\section{$4 \cdot 1$ 上部返却カスケート}

ガス循罯液取出しの場合，すし $N$ とッが与えられれ ば Fig. 9 のことく（24）式によりてを種々变化ざせて $\theta$ 対 $\beta$ の線図をえがき，それと同一の图表上に非混合の 条件 (40) 式を点緅し，その交点上り非混合条件を满足 する $r$ 対 $\beta$ の関係を Fig. 10 のことく求めることができ る。この関係を（46）式に代入すると種々のてに対する $V_{\beta}$ の関係を求めることができる。Fig. $11 に N=5$ で を変数とした場合の $\gamma$ 対 $V_{\beta}$ の関係を示した。図より明

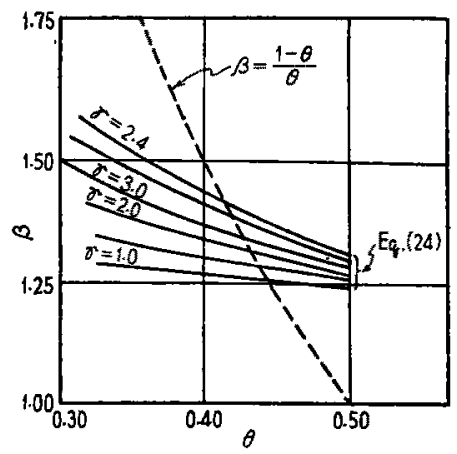

Fig. $9 \forall \beta, N=5, \kappa=1, \gamma=$ parameter 


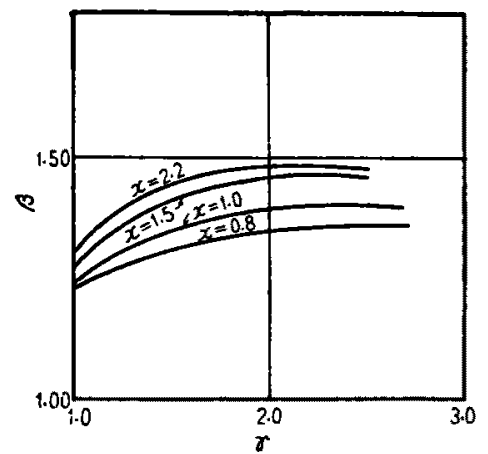

Fig. $10 \quad r$ vs $\beta, N=5, \kappa=$ parameter

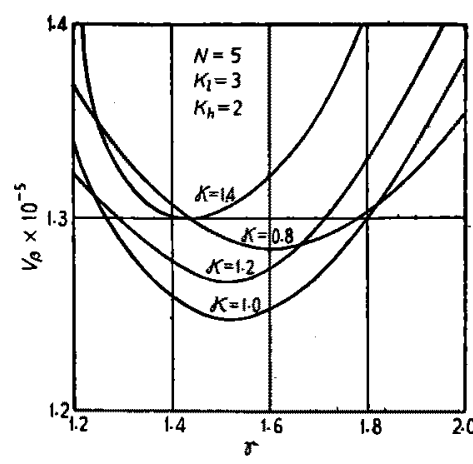

Fig. $11 r$ vs $V_{S}, N=5, \kappa=$ parameter

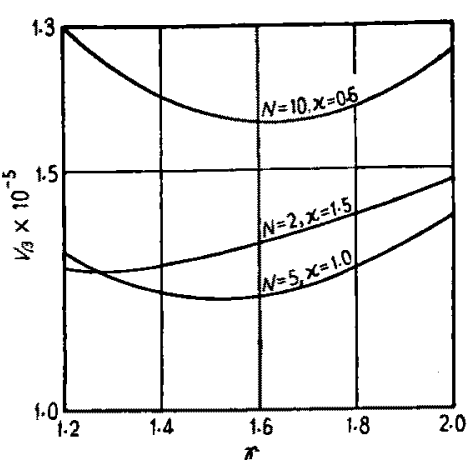

Fig. $12 r$ vs $V_{\beta}$
らかなことく Topt=1.5のとき $V_{\beta}$ の最小值を与える。なお段数 $N$ が 梁化すれば "opt, ropt b变化する。たとえば $N=2$ の場 合 $\kappa_{\mathrm{opt}}=1.5, \quad \gamma_{\mathrm{opt}}=1.3, N=10$ の場合 $\kappa_{\mathrm{opt}}=0.6$, $\gamma_{\mathrm{opt}}$ $=1.7$ のごとく段数 $N$ が增大するととるに кopt は小に, roptは大となる。

Fig. 7，8に示したような全還流の場合単一荅で及の 最大值を与克る ropt は $K_{l}=2, K_{h}=3$ の間に，すなわ ら $2<$ Topt<3 に存在したが，カスケードに組んだ場合 の roptは，2 より小さい方に寄っていることに泩目すべ きである。すなわち単一ステージでの ropt とカスケー ドにしたときの ropt とは異なった值をとる。つぎ種 々の段数にたいして $V_{\beta}$ の最小值を与える を取り出し，Fig. 12 の5に点緅してみると， $N_{\text {opt }}=$ 5, $\kappa_{\mathrm{opt}}=1$ ， ropt $=1.5$ のとき $V_{B}$ の最小值を与えること がわかる。

液循還ガス取出しの場合る同様に（29）（40）式より 非混合条件を满足する $\beta$ 対 $\gamma$ の関保を求め (49) 式に代 入して種々のケに対する $V_{\beta}$ を点緅し， $V_{\beta}$ の最小値を求 ぬることにより ropt, $\kappa_{\text {opt }}$ なとが求められる。

\section{4-2 中央部返却カスケート}

この場合上部返却カスケードのことく非混合条件は必 要でないが，所要同位元素収率 $\eta\left(=\tau / F x_{F}\right)$ が与え れれば，第1ステージでの物質収支より（52）式のこ とき関係が成立する。

$$
A \delta=\tau / F x_{F}=\eta
$$

上部返却カスケードの回収率を考えると，物質収支を あらわす $F=P+W, F x_{f}=P x_{P}+W x_{W}$ より供給流量 $F$ は

$$
F=P\left(x_{P}-x_{W}\right) /\left(x_{f}-x_{W}\right)
$$

上部返却非理合カスケード枕和いては， $\alpha=\beta^{2}$ の関係 が成立するから (15)，(16）式の $\alpha ， \beta$ の定義により

$$
x_{\mathrm{W}}=x_{F} / \boldsymbol{B}
$$

したがって, 上部返却の場合の回収率 $\eta=P_{x_{P}} / F x_{F}$ は
(59) 式のことく表わされる。

$$
\eta=(\beta-1) /\left(\beta-x_{F} / x_{P}\right)
$$

カスケード問題で $x_{F}$, xp が与去られているため, 上部返却の場合， $\beta$ を決定すれば回収密 $\eta$ が定まる。と ころが中央部返却カスケードでは $(52)^{\prime}$ 式に示すよ5に Bが決まって子回収率 $\eta$ は定まらない。

中央部返却液取出しカスケードの場合, 分離係数及は (30) 式に示すことく、液ガス比 $\gamma$ 特よひ薄まり係数。の 函数となっている。したがって，泥合の条件 (52) 式と （30）式とを同㭙に淽足する $\tau, \beta$ 関係については Fig. 13 に示すごとくクをパラメーターとして縦軸に及を, 横軸に $\delta$ をとり (52) 式の関係を点綴し，同图に（30）

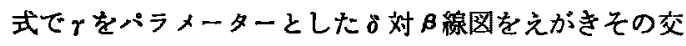
点より释々のクに対する $r$ 対 $\beta$ 関係を求める。Fig. 14 に $N=8, \kappa=1$ の場合の $r, \beta$ 関保を示した。Fig. 14 K 示したことくクの減少とともに日は增し，塔容積は減少 する方向にはたらく。一方クの減少により塔容皘は増大 する方向にはたらく。したがって荅容積は回収率によっ て最小值が存在する。 $N=5$ の場合における塔容䖽対回 収靿りの関係を Fig. 15に示した。同時に，この因より ropt あ求めることができる。すなから $N=5, k=1$ で $\eta_{\mathrm{opt}}=0.179$, ropt=2.1 である。段数を種ヶ变化して

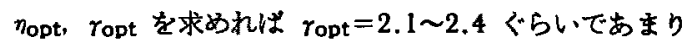
変化しないが $\eta_{\text {opt }}$ は $N=5$ のとき $\eta_{\text {opt }}=0.179, N=10$ のとき $n_{\mathrm{opt}}=0.250, N=15$ のとき $\eta_{\mathrm{opt}}=0.278$ のこと く段数が增加するにつれて，最適収率はよくなる。つき に，種々の段数について最適収率の線图のみを取り出し Fig. 16 に点棳した。中央部返却ガス取出しの場合につ いてす同様にして行ならことができる。

\section{5. カスケートの設㖕およひ比较}

\section{$5 \cdot 1$ 設計法骤要}

問題は入口濃度 $x_{F}$ の原料から所要同位元素輸送量が $\boldsymbol{\tau}\left(=\boldsymbol{P}_{x_{P}}\right)$ になるよ5な，同位元素分離カスケード荅の最 


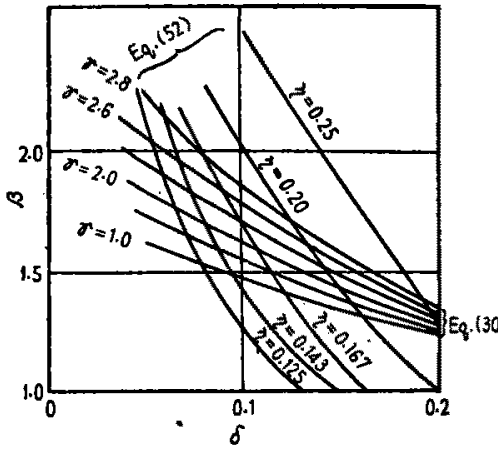

Fig. $13 \delta$ vs $\beta, N=5, \kappa=1, \gamma=$ parameter

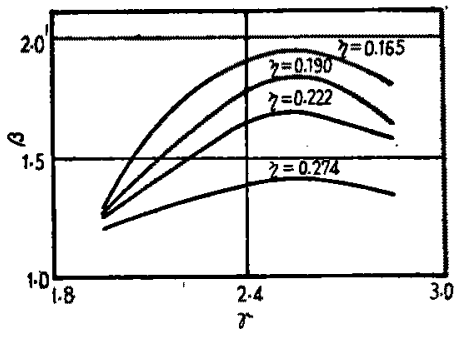

Fig. 14

$r$ vs $\beta, N=5, \kappa=1, n=$ parameter

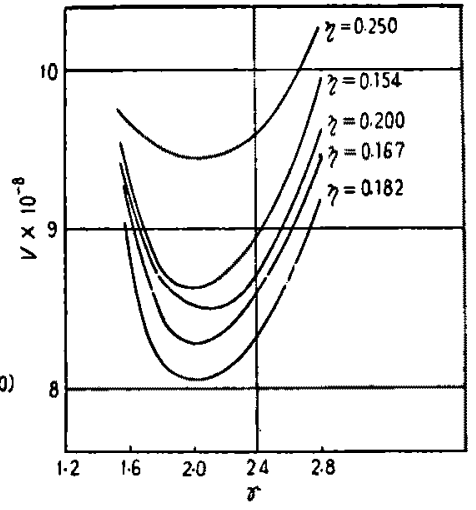

Fig. $15 \quad r$ vs $V, N=5, x=1, n=$ parameter

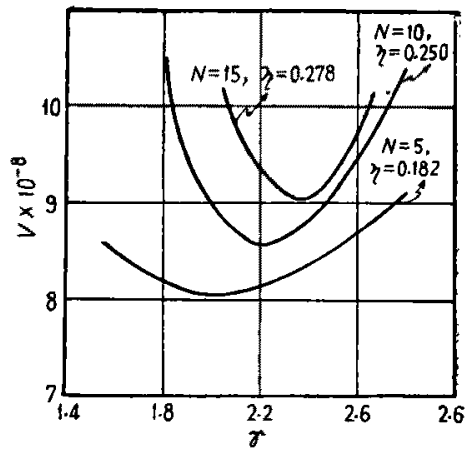

Fig. $16 \quad r$ vs $V$
適大きさ， 最適操作条 件をるとめ ることであ り，最大の 着眼点は最 終製品の価 格をでをる だけ低くす ることであ る。二重温度交換反応カスケードては，考虑すへき媒介 变数の数が多く操作王力, 操作温度, 低温塔殷数などを 適当にとる。低温塔温度 $T_{l}$ を一定保った場合 $T_{h}$ を きわめて高くとれば，分離係数は大きくなり比較的小さ

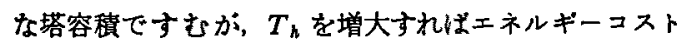
が著しく増大するため適当な高温荅温度 $T_{h}$ が存在す る。一方 $T_{h}$ が定まれば，その飽和蒸気压から最低所要 操作圧力 $p_{\min }$ 名決定される。

i）上部遮却力スケード段数 $N$ を適当に決定す れば前述のことく $V_{\beta}$ の追求により Kopt, Bopt, $\theta_{\text {opt }}$, Topt が求まる。この場合最適原料 $F$ は $\boldsymbol{\beta}_{\mathrm{opt}}$ が決定されれば （60）式より求をる。

$$
F=\frac{P}{(\beta-1)}\left(\beta \frac{x_{P}}{x_{F}}-1\right)
$$

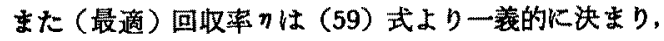
ステーシ数 $S$ は

$$
S=\ln \frac{x_{P}}{x_{F}} / \ln \beta
$$

である。

つきに回收率クが与えられている場合は $F$ ，种が決 定され，したがって濃度のみの函数となっている（47）

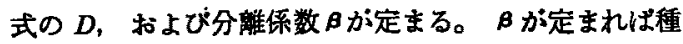
々の rに対し非混合条件を満足し，かつ所定の日を示す

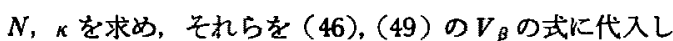
$V_{\beta}$ D追求より Topt, $N_{\text {opt }}$, kopt מ゙氵夯定される。

ii）中央部返却カスケート 段数 $N$ が与えられれ ば前述のことく，回収率 $\eta$ を種々変化し混合条件を満足 寸る $\gamma$ 対 $\beta$ の関係求め (55)，(56）式あるいは（58）, （56）式に代入し Fig. 15 のことくクをバラメーターと

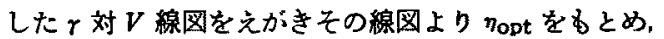

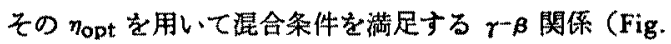
14）より $V_{\beta}$ の最小值を启求することにより

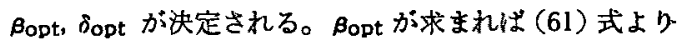
所要ステージ数 $S$ を求めることができる。

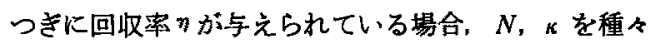

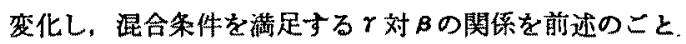
くして求め， $V_{B}$ の最小值を追求することにより $N_{\text {opt }}$.

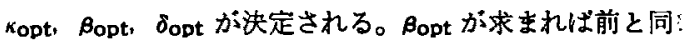
様に (61) 式より所要ステージ数 $S$ を求めることができ る。

iii）設計例 W低温塔温度 $70^{\circ} \mathrm{C}\left(K_{l}=3.00\right)$, 高温塔温度 $200^{\circ} \mathrm{C}\left(K_{k}=2.00\right)$ で低温塔，高温塔と的に 理論段数 5 段の二重温度交換反応塔を用い, 原料組成 $x_{F}$ $=0.00015$, 原子分率より $x_{P}=0.01$, 原子分率の製品を

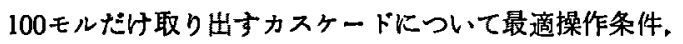
所要ステーシ数, 所要原料, 総循還量, 総塔容積, 最適 回収率などを求めてみる。

上部返却液取出しカスケードの場合，前述のことく。

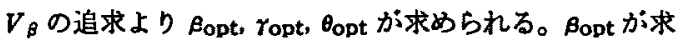
まれば非混合条件より（62）式で廃裹流洔度 $x_{W}$ が求ま Ђ。

すでに述べたように，上部返却非混合カスケードでは つきの関係がある。

$$
x_{W}=x_{F} / \beta
$$

$x_{W}$ が求まれば原料 $F$ は (60) 式より，総流量 $\sum L_{i}$ ，総 塔容箖Vは(43)，(42) 式より求めることができる。一- 


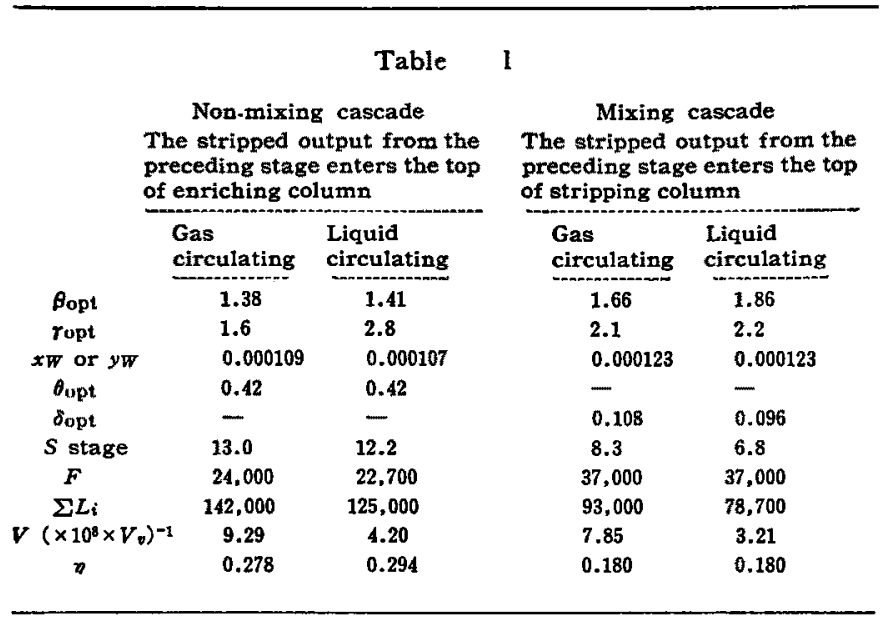

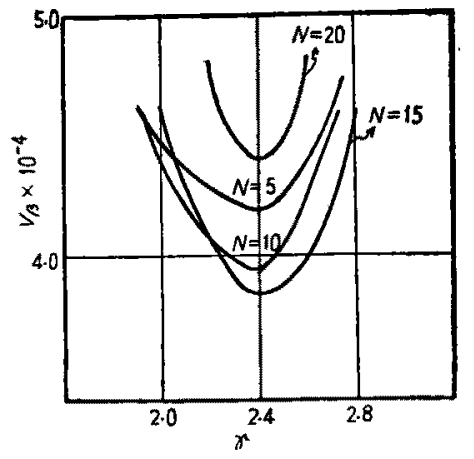

Fig. $17 \gamma$ vs $V_{\hat{\beta},} \varepsilon=1, \eta=$ $0.278, N=$ parameter

を比較する場合，原料コストを考虑す れば同じ回收率について比較しなけれ

方回收率クは（59）式より求まる。ガス取り出しの場合 子同様 $V_{\beta}$ の追求より $\beta_{\text {opt }}, \gamma_{\text {opt }}, \theta_{\text {opt }}$ が求まり，同様に して総流量，総塔容積，回収率などを求めることができ る。

中央部返却液取り出しの場合，前述のことき解析より

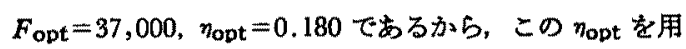
いて $V_{B}$ の追求より ropt， $\delta_{\text {opt }}, \beta_{\text {opt }}$ などを求めること ができる。后隹 が求まればステージ数 $S$ が (61) 式よ $\eta$, 総流量 $\Sigma L_{i}$, 総塔容積 $V$ などが (53)，(54) 式よ り求まる。がス取出しの場合す $\eta_{\mathrm{oDt}}=0.180$ として $\beta_{\mathrm{opt}}$ ropt, $\theta_{\text {opt, }}$ 総流量, 総塔容積などを前と同様に求めるこ とができる以上の計算結果を Table 1 亿示した。

Table 1 上り理論段数 $N=5, k=1$ の場合, 中央部返 却カスケードより上部返却カスケードの方が回収率はよ いが, 総流量、総荅容積は中央部返却カスケードの方が 少なくてすむ。したがって原料コストを無視した場合，

一定量の重水素を取り出すには、中央部返却カスケード 飞組むのが経済的であろうと考えられる。

\section{$5 \cdot 2$ 各理カスケードの比较}

各カスケードに捻いてて，ガス取り出しの場合と液取り 出しの場合とで $N, \kappa$ を一定とすれば Bopt の值はほとん ぞ等しいため，液取り出しの場合とガス取り出しの場合

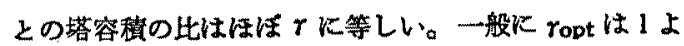
ク大なるため最適条件で操作する埸合，液取り出しの場 合の方がガス取り出しの場合より塔容㮹は大きくなる。 乙かし重水として生産する場合, 濃縮した重水素を何ら かの方法で重水に变換しなければならない。またガス取 ク出しカスケードの場合の roptは全遥流の埸合の ropt とほぼ等しいが, 液取り出しカスケードの roptは全遠流 の roptより小さい值となる。

つぎ中央部返却カスケードと上部返却カスケードと
ばならない。たとえば Table 1 に和いて上部返却カス ケードの回収率 $\eta=0.278$ に等しく中央部返却カスケー ドの回収率をとれば，前述のことく $N$ を種々変化させて 総塔容積を求めてに対して点綴すると Fig. 17 のことく なる。Fig. 17 より最適理論段数 $N=15$ となりそのとき の総塔容櫍 $V=9.3 \times 10^{8} \times V$ となり，上部返却カスター ドの総塔容精とほぼ等しくなる。しかしながら原料コス トを無視すれば，中央部返却カスケードの回収率は覀く なるが Table 1 亿示すように, 中央部返却カスケードの 方が建設費が少なくてすむ。

\section{6. 結 語}

同位元素の低澧度蛨縮に用いられる二重温度交換カス ケードの一設計法を提出し, 各種カスタードの解析を行 ない最適条件の求め方について考察した。また各単一二 重温度交換反応塔をカスケードに組む場合，中央部返却 カスケードでは回収率が低くなるが，その塔容程は上部 返却カスケードの総塔容賴より少なくてすむので，水を 原料として重水を製造するような場合，必ずしる Cohen らが提出している非混合上部返却カスケードに組さ必要 はなく、二重温度交換カスケード特有の中央部返却カス ケード組む方が経济的になる場合るある。

以上の諸考察は数值解析的な面が多く今後より簡単な 設計法を追求してゆくへきであると考える。また中央部

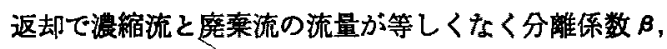
薄まり保数るなどがカスケードを通じて一定でない場合 についての考察す今後にのこされた問題である。

\section{Nomenclatures}

$K$ : equilibrium constant of exchange reaction $x$ : atom fraction of deuterium in liquid 


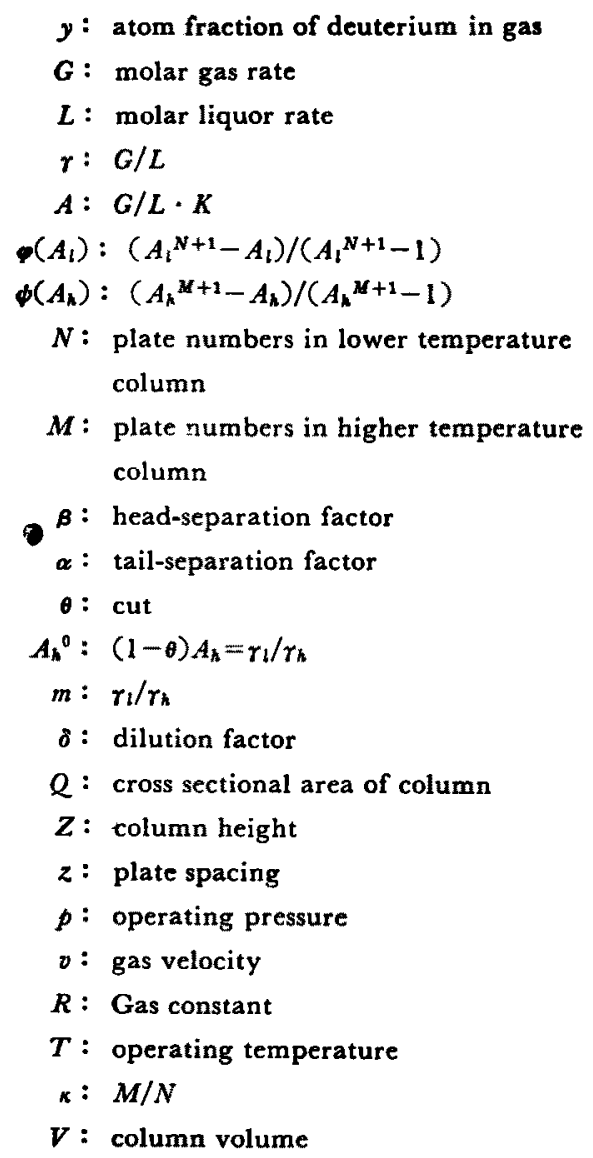

$$
\begin{aligned}
& S: \text { total stage number } \\
& P: \text { molar product rate } \\
& F: \text { molar feed rate } \\
& W: \text { molar waste rate } \\
& \tau: \text { net deuterium transport } \\
& \eta: \text { fractional recovery }
\end{aligned}
$$

\section{Subscript and Superscript}

$$
\begin{aligned}
h & : \text { higher temperature column } \\
l & : \text { lower temperature column } \\
P & : \text { product } \\
F & : \text { feed } \\
W & : \text { waste } \\
U: & \text { non-mixing cascade } \\
C: & \text { mixing cascade } \\
L: & \text { gas closely circulating } \\
G: & \text { liquid closely circulating } \\
\text { opt }: \text { optimum condition resulting in minimum } & \text { total column volume }
\end{aligned}
$$

\section{Literatured cited}
1) E. W. Becker: Angew. Chem., 68, 6 (1956)
2) K. Cohen: "The Theory of Isotope Separation" (1951) McGraw Hill.
3) M. Benedict, T, H. Pigford: "Nuclear Chemical Engneering" (1957) MeGraw Hill.
4) E. Cerrai, et all : Chem. Eng. Progr, Symp. Ser. 50, 271 (1954)
5) K. Bier : Chemie.Ing. Techn. 2B, 625 (1956)

\title{
Optimum Conditions for the Dual Temperature Exchange Process of Producing Heavy Water
}

\author{
T. Mizushina ${ }^{13}$, T. Takamatsu", A. Yoshida ${ }^{22}$ \\ A. Nakanishi ${ }^{2)}$, M. Kono ${ }^{3)}$ and H. Sayama")
}

The equations which represent the head-separation factors of the dual-temperature-exchange columns are derived and the optimum operating conditions for them as well as the design of the columns to bring about the following four possible cascade schemes are discussed.

Cascade Schemes :

Non-Mixing cascade (Cf. Fig. 3)

The stripped output from the second stage enters the top of the enriching column together with the enriched output from the first stage.

Scheme 1: Gas is circulated.

Scheme 2: Liquid is circulated.

Mixing cascade (Cf. Fig. 4)

The stripped output from the second stage enters the top of the stripping column.

Scheme 3: Gas is circulated. 
Scheme 4: Liquid is circulated.

Assumptions :

(1) Only the low-deuterium-content region is made the subject of study.

(2) Liquid-phase catalysts may be employed in these cascades, although no catalyst will be necessary in water- $\mathrm{H}_{2} \mathrm{~S}$ system.

(3) The cross sectional area of each column is proportional to its gas throughput.

(4) The stage variables $\left(r, N, n, \delta, T_{l}, T_{n}\right.$ etc. ) are constant throughout each of the entire cascades.

Summaries of the results obtained are as follows:

(1) The head separation factors $\beta$ are given by the following equations.

Scheme 1: $\quad \beta=\frac{A_{l} / \varphi\left(A_{l}\right)+A_{h} / \psi\left(A_{h}\right)-\left(1+A_{l}\right)}{A_{l} / \varphi\left(A_{l}\right)+A_{h} / \psi\left(A_{h}\right)-\left(1+A_{h}{ }^{0}\right)}$

Scheme 2: $\quad \beta=\frac{1 / \varphi\left(A_{l}\right)+1 / \psi\left(A_{h}\right)-\left(1+1 / A_{h}\right)}{1 / \varphi\left(A_{l}\right)+1 / \psi\left(A_{h}\right)-\left(1+1 / A_{l}{ }^{0}\right)}$

Scheme 3: $\quad \beta=\frac{A_{l} / \varphi\left(A_{l}\right)+A_{h} / \psi\left(A_{h}\right)-\left(1+A_{l}\right)}{A_{l} / \varphi\left(A_{l}\right)+A_{h} / \psi\left(A_{h}\right)-\left\{1+m(1-\delta) A_{h}\right.}$

Scheme 4: $\quad \beta=\frac{1 / \varphi\left(A_{l}\right)+1 / \psi\left(A_{h}\right)-\left(1+1 / A_{h}\right)}{1 / \varphi\left(A_{l}\right)+1 / \psi\left(A_{h}\right)-\left\{1+m(1-\delta) / A_{l}\right\}}$

(2) The total volumes of the enriching and stripping columns, $V$, are given by :

Scheme 1: $\quad V=(R z / p v)\left\{N_{\gamma}\left(T_{l}+{ }_{\kappa} T_{k}\right)(\beta+1) /(\beta-1) \ln \beta\right\}\left(F \ln x_{F}-P \ln x_{P}-W \ln x_{W}\right)$

Scheme 2: $\quad V=(R z / p v)\left\{N\left[T_{1}(1-\theta)+\kappa T_{h}\right](\beta+1) /(\beta-1) \ln \beta\right\}\left(F \ln y_{F}-P \ln y_{P}-W \ln y_{W}\right)$

Scheme 3: $V=(R z / p v)\left\{N r\left(T_{l}+{ }_{k} T_{h}\right)_{\beta} /(\beta-1)\right\}\left\{F\left(1-x_{F} / x_{P}\right)\right\}$

Scheme 4: $V=(R z / p v)\left\{N\left(T_{1}+\kappa T_{h}\right) \beta /(\beta-1)\right\}\left\{F\left(1-y_{F} / x_{P}\right)\right\}$

(3) Some numerical calculations are carried out for each of the cascade schemes and the following results are obtained.

a) There is an optimum condition for the minimum total volume of the cascade, and it depends upon the variables of each stage.

b) The liquid circulating cascade is preferable to the gas circulating cascade.

c) If the cost of feed may be left out of consideration, the cascade of Scheme 4 will be the most preferable, as shown in Table 1 .

1) Engineering Research Institute, Kyoto University

2) Dept. of Chem. Eng., Kyoto University

3) Asahi Chemical Industry Co.

4) Kansai Electric Power Co.

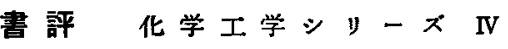

白井隆 流

終戦後米国石油工業の流動触媒法の成功が伝えられて 以来、流勤麗ブームの一眭期があった。固体の連続処理 に，気相接触反応に，乾燥に，その他数多くの工業化の 試みがなされ、これに開して数多くの特許，実用新案が 提出され：また基碟研究の面でも数多くの実娩と発表か 行われた。

今日では何てる一皮流動層でという時期から、これに

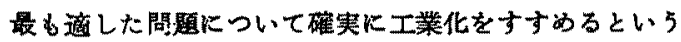
普㬰な安定した段階に来ている。しかし現在のところ流 動周に関してまとまった成書は祜くほど少い。
動居科学技術社 発行

本書は内外において従来数多く発表された流動風の基 整的な面の研究を，著者のこの部面での永年の知識をむ ってょく整理し，わかり易く説明したもので，今日の流 動層の基礎的研究がとこまで到達しているのか，それを どのように利用するのかを 13 章にわたって述へたもの である。記述む平明て初心者にもかかり易く，流動層の 基㯬研究面の現在の全貌を把㨄するために，現在流動冏 の実験をしている人にる，これから㕸めよ5とする人に む一読の必要があるるのと思う。

（渡会 正三） 